\title{
In vitro study of baseline sensitivity of important fungi against differ ent fungicides
}

\author{
Sanjay Goswami ${ }^{2 *}$, R. K aur ${ }^{2}$ and Dipak T. Nagrale ${ }^{1}$ \\ ${ }^{1}$ National Bureau of Agriculturally Important Microorganisms (NBAIM), Kusmaur, Mau Nath Bhanjan, 275101 (UP), \\ INDIA \\ ${ }^{2}$ Department of Plant Pathology, Punjab Agricultural University, Ludhiana -141004, INDIA \\ *Corresponding author. E-mail: sanjaygoswami65@ gmail.com \\ Received: J uly 15, 2012; Revised received: A ugust 14, 2012; Accepted: 0 ctober 25, 2012
}

Abstract: Baseline sensitivity values of important phytopathogenic fungi were studied against fungicides. $E_{50}$, $\mathrm{ED}_{90}$ and MIC value of propiconazole for, Colletotrichum capsici, and Gloeosporium ampelophagum was in the range of $0.020-0.04 \mu \mathrm{g} / \mathrm{ml}$. $E_{50}$ values of tebuconazole for Alternaria alternata was $30.0 \mu \mathrm{g} / \mathrm{ml}$. Azoxystrobin was also tested for its $\mathrm{ED}_{50}, \mathrm{ED}_{90}$ and MIC values against Alternaria alternata, C. capsici, G. ampelophagum and B otrytis cinerea where the values were in the range of $0.019-50.0,0.03-60.0$ and $0.2-100.0 \mu \mathrm{g} / \mathrm{ml}$ respectively. Baseline sensitivity values are important for the management of plant diseases and resistance development.

Keywords: Baseline sensitivity, Fungicide, Fungi, In vitro

\section{INTRODUCTION}

Phytophthora infestans, Phytophthora parasitica, Pseudoperonospora cubensis, Uncinula necator, Gloeosporium ampelophagum, Alternaria alternata, Colletotrichum capsici and Botrytis cinerea are important plant pathogens and causes late blight of potato, citrus gummosis, downy mildew of cucurbits, powdery mildew of grapes, anthracnose of grapes and leaf spot, leaf blight on chilli and gray mold respectively. Fungicide resistance and its management are of great importance to all concerned with crop protection. Without effective product management, resistance could arise very quickly, as happened with the methyl benzimidazole, carbamates, dicarboxymides and phenylamides in the early 1980s. The key factor in preventing resistance is to know the response of target fungi to the fungicide before the fungus has been exposed to it in practice. Thus there is need to know the baseline sensitivity for the fungus. With this information it is possible to monitor the effect of fungicides on fungus if the response is changing towards résistance. In the study $P$ infestans, $P$ parasitica, P. cubensis, U. necator, G.ampelophagum, A. alternata, $C$.capsici, and $B$. cinerea were tested for their baseline sensitivity against metalaxyl 35DS (Apron), triadimefon 35WP (Bayleton), propiconazole 25 EC (Tilt), tebuconazole $250 \mathrm{SC}$ (Folicur), azoxystrobin $25 \mathrm{SC}$ (Amistar), Mancozeb 75 WP(Indofil M-45), carbendazim 75 WP (Bavistin) and carboxin 75 WP (Vitavax). Baseline sensitivity of some important fungal pathogens of other crops to the strobilurin (Amistar) fungicides has been established (Olaya and Koller, 1999, Wong and Wilcox,
2000, Wong and Wilcox, 2002). Baseline sensitivities of several pathogens to fenbuconazole and other triazole fungicides have been determined as well (McGtath et al., 1996, Reynold et al., 1997, Smith et al., 1991).

To establish baseline sensitivity values for the major fungal pathogens of different crops, all isolates were collected from the place not previously treated with the tested fungicides. All the isolates collected in year 2009 were not exposed to any of these products.

\section{MATERIALS AND METHODS}

In vitro poisoned food method was used to find out the $\mathrm{ED}_{50}, \mathrm{ED}_{90}$ (fungicide concentration at which 50 and $90 \%$ population of the fungus is restricted) and MIC (minimum inhibitory concentration) values of different fungicides by using dose response curve. Purified cultures were obtained of all the fungi. The test was conducted on PDA medium amended with different concentrations i.e. $0,1,5,10,20,50,100,500$ and $1000 \mu \mathrm{g} / \mathrm{ml}$ of all the tested fungicides. For all studies, commercial formulations of the entire product were used. Colony diameter was measured across two axes and averaged. There were three replications for each treatment. Percent germination inhibition was recorded in each case at different concentrations of the tested fungicides and was compared with control.

\section{RESULTS AND DISCUSSION}

The data presented in the Table 1 showed that $\mathrm{ED}_{50}, \mathrm{ED}_{90}$ and MIC value of propiconazole for, C. capsici, and G. ampelophagum was in the range of $0.020-0.04 \mu \mathrm{g} / \mathrm{ml}$, while $\mathrm{ED}_{90}$ values were in the range of $0.040-1.0 \mu \mathrm{g} / \mathrm{ml} . \mathrm{ED}_{90}$ 
Table 1. In vitro study of baseline sensitivity of important fungi against different fungicides.

\begin{tabular}{|c|c|c|c|}
\hline $\begin{array}{l}\text { Fungicide } \\
\text { Fungal pathogen }\end{array}$ & $\mathrm{ED}_{50}$ & $\begin{array}{l}E_{90} \\
(\mathrm{~g} / \mathrm{ml})\end{array}$ & $\mathrm{MIC}$ \\
\hline \multicolumn{4}{|c|}{ Tilt 25EC (propiconazole) } \\
\hline C. capsici & 0.020 & 0.040 & 0.192 \\
\hline G.ampelophagum & 0.04 & 1.0 & 1.0 \\
\hline \multicolumn{4}{|c|}{ B ayleton25W P (triadimefon) } \\
\hline U. necator & 0.03 & 0.1 & 0.5 \\
\hline \multicolumn{4}{|c|}{ A pron 35DS(metalaxyl) } \\
\hline P. infestans & 2.0 & 4.0 & 7.0 \\
\hline P. parasitica & 0.3 & 1.0 & 1.0 \\
\hline P. cubensis & 2.0 & 5.0 & 5.0 \\
\hline \multicolumn{4}{|c|}{ Folicur 250EC (tebuconazole) } \\
\hline A. alternata & 30.0 & 60.0 & 100.0 \\
\hline \multicolumn{4}{|c|}{ A mistar 25SC (azoxystrobin) } \\
\hline A. alternata & 50.0 & 60.0 & 100.0 \\
\hline C. capsici & 0.019 & 0.03 & 0.2 \\
\hline G. ampelophagum & 0.03 & 0.06 & 1.0 \\
\hline B. cinerea & 0.042 & 0.09 & 1.0 \\
\hline \multicolumn{4}{|c|}{ Indofil M -45 (M ancozeb 75W P) } \\
\hline C. capsici & 30.0 & 40.0 & 50.0 \\
\hline \multicolumn{4}{|c|}{ Bavistin 75W P (Carbendazim) } \\
\hline C. capsici & 900.0 & 1000.0 & 1000.0 \\
\hline G.ampel ophagum & 0.025 & 0.05 & 0.1 \\
\hline B. cinerea & 0.1 & 0.2 & 0.5 \\
\hline \multicolumn{4}{|c|}{ Vitavax 75 W P (carboxin) } \\
\hline B. cinerea & 0.05 & 1.0 & 1.0 \\
\hline
\end{tabular}

$\mathrm{MIC}=$ Minimum inhibitory concentration, $\mathrm{ED}=$ Effective dose values of triadimefon against $U$. necator was $0.1 \mu \mathrm{g} / \mathrm{ml}$. $\mathrm{ED}_{90}$ values of metalaxyl against P. infestans, P. parasitica and $P$. cubensis was 4.0, 1.0 and $5.0 \mathrm{ig} / \mathrm{ml}$ respectively. $\mathrm{ED}_{50}$ values of tebuconazole for $\mathrm{A}$. alternata was 30.0 $\mu \mathrm{g} / \mathrm{ml}$. Azoxystrobin was also tested for its $\mathrm{ED}_{50}, \mathrm{ED}_{90}$ and MIC values against $A$. alternata, $C$. capsici, G. ampelophagum and $B$. cinerea where the values were in the range of $0.019-50.0,0.03-60.0$ and $0.2-100.0 \mu \mathrm{g} / \mathrm{ml}$ respectively. $\mathrm{ED}_{90}$ value of Mancozeb $75 \mathrm{WP}$, carbendazim $75 \mathrm{WP}$ and carboxin $75 \mathrm{WP}$ against $C$. capsici, G. ampelophagum and $B$. cinerea was in the range of 0.05 $1000.0 \mu \mathrm{g} / \mathrm{ml}$. According to Mondal et al. (2005) values for azoxystrobin ranged from a low of $0.06 \mu \mathrm{g} / \mathrm{ml}$ with $\mathrm{E}$. fawcettii to a high of $>100.0 \mu \mathrm{g} / \mathrm{ml}$ with A, alternata. With $C$. graminicola, the $\mathrm{ED}_{50}$ values in relation to azoxystrobin were 0.01-0.1 $\mu \mathrm{g} / \mathrm{ml}$ (Day et al., 1995).

\section{Conclusion}

The present study concluded that baseline sensitivity values of these fungi are important for the proper and timely management of the plant diseases. It would also be helpful in controlling the development of resistance.

\section{REFERENCES}

Day, D.A., Whelan, J., Millar, A. H., Siedow, J. N. and Wiskich,
J. T. (1995). Regulation of the alternative oxidase in plants and fungi. Aust. J. Plant Physiol., 22: 497-509.

McGrath, M.T., Staniszewska, H., Shishkoff, N. and Casella, G. (1996). Fungicide sensitivity of Sphaerotheca fuliginea populations in the United States. Plant Dis., 80: 697-703.

Mondal, S.N., Bhatia, A., Shilts, T. and Timmer, L. W. (2005). Baseline sensitivities of fungal pathogens of fruit and foiliage of citrus to azoxystrobin and fenbuconazole. Plant D is., 89: 1186-1194.

Olaya, G. and Koller, W. (1999). Baseline sensitivities of Venturia inaequalis populations to the strobilurin fungicide kresoxim methyl. Plant D is., 83: 274-278.

Reynolds, K.L., Brenneman, T. B. and Bertrand, P.F. (1997). Sensitivity of Cladosporium caryigenum to propiconazole and fenbuconazole. Plant D is., 81: 163-166.

Smith, F.D., Parker, D. M. and Koller, W. (1991). Sensitivity distribution of Venturia inaequalis to the sterol demethylation inhibitor flusilazole: Baseline sensitivity and implications for resistance monitoring. Phytopathology, 81: 392-396.

Wong, F.P. and Wilcox, W. F. (2002). Sensitivity to azoxystrobin among isolates of $U$ ncinula necator: Baseline distribution and relationship to myclobutanil sensitivity. Plant Dis., 86: 394-404.

Wong, F.P. and Wilcox, W. F. (2000). Distribution of baseline sensitivities to azoxystrobin among isolates of Plasmopara viticola. Plant D is., 84: 275-281. 